\title{
Assessment of commercial flower crops as intercropping system in coconut garden for additional returns
}

\author{
Nagappa Desai*, Chandru Patil ${ }^{1}$ and Nagaraj Kusagur ${ }^{2}$ \\ Krishi Vigyan Kendra (U.A.S.), Konehalli, TUMKURU (KARNATAKA) INDIA \\ (Email : agridesai@gmail.com)
}

\begin{abstract}
The farm trials was conducted for assessment of commercial flower crops as intercropping system in coconut garden for additional returns at farmer's field of Gubbi taluk, Tumkur district of Karnataka state to study the influence of intercropping system on coconut yield, economics of coconut based intercropping system with commercial flower crops. The experiment consisted of four different intercropping systems viz., coconut sole cropping as farmers practice $\left(\mathrm{T}_{1}\right)$, coconut + marigold $\left(\mathrm{T}_{2}\right)$, coconut + china aster $\left(\mathrm{T}_{3}\right)$ and coconut + chrysanthemum $\left(\mathrm{T}_{4}\right)$ with seven replication (trials) in 38 year old coconut garden of Tiptur tall variety planted with a spacing of $9 \mathrm{mx} 9 \mathrm{~m}$. The results of experiment show that growth and yield parameters of coconut were not significantly affected by growing commercial flower crops such as marigold, china aster and chrysanthemum. The yield of coconut was found to higher (8932 nuts/ha/year) under chrysanthemum as intercrop in coconut garden, which was on far with other intercrops in coconut garden. The highest net annual income Rs. 1,43,810/ha and B:C ratio 3.13 were recorded in coconut + chrysanthemum intercropping system with more additional income and market demand of chrysanthemum, which was on far with coconut + China aster (Net annual income Rs. 1,13,300/ha and B:C ratio (3.06) and less market demand of marigold, where as lowest net annual income Rs. 47,310/ha and B:C ratio 2.26 were recorded in coconut sole cropping with no additional income from the farmers practices.
\end{abstract}

Key Words : : Assessment, Coconut, Flower crops, Income, Intercrops, Yield

View Point Article : Desai, Nagappa, Patil, Chandru and Kusagur, Nagaraj (2018). Assessment of commercial flower crops as intercropping system in coconut garden for additional returns. Internat. J. agric. Sci., 14 (1) : 202-206, DOI:10.15740/HAS/IJAS/14.1/ 202-206.

Article History : Received : 05.09.2017; Revised : 02.12.2017; Accepted : 14.12.2017

\footnotetext{
* Author for correspondence:

${ }^{1}$ Department of Horticulture, College of Horticulture (U.A.H.S.), Hiriyur, CHITRADURGA (KARNATAKA) INDIA

${ }^{2}$ Department of Fruit Science, College of Horticulture, (U.A.H.S.), Hiriyur, CHITRADURGA (KARNATAKA) INDIA
} 